\title{
Biološke, ekološke i krajobrazne karakteristike bagrema (Robinia pseudoacacia L.) s primjenom na zelenim površinama grada Knina
}

\author{
Biological, ecological and landscape characteristics \\ of black locust (Robinia pseudoacacia L.) used in green \\ spaces of the city of Knin
}

\section{B. Dorbić, Božana Vučemilović Alegić, Emilija Friganović, Anita Pamuković, EIma Temim, Alisa Hadžiabulić}

\section{SAŽETAK}

Bagrem (Robinia pseudoacacia L.) je brzorastuće, listopadno drvo iz Sjeverne Amerike, a u Europu je uvezen početkom 17. stoljeća. Cijenjen je u pčelarstvu, drvnoj industriji, šumarstvu te je vrlo invazivna vrsta. Najrasprostranjeniji je u sjeveroistočnom dijelu Hrvatske. Vrsta posjeduje i dekorativne osobine pa se koristi i u ukrasnoj hortikulturi. Metodom promatranja tijekom travnja i svibnja 2016. godine na području grada Knina zamijećena je slaba zastupljenost ove vrste u vrtovima, okućnicama i zelenim površinama. U pogledu održavanja nužno je posvetiti više njege kako bi stabla dobila na većoj estetskoj vrijednosti, koja je sada na razini prosječnosti. Uviđa se i invazivno ponašanje vrste što se ogleda u zastupljenosti na određenim nepejsažnim površinama (slobodno rastuća vegetacija uz cestu, rubove šume, željezničku prugu itd.). Najgora aktivnost bagremove invazivnosti je potiskivanje autohtonih vrsta. Metodom anketnog ispitivanja ispitanici s područja grada Knina i okolice s vrlo dobrim ocjenama vrednuju atraktivnost, ugodnost $i$ utjecaj bagrema na duševno zdravlje čovjeka. S nešto slabijim ocjenama vrednuju primjenu bagrema u gospodarstvu, krajobraznoj slikovitosti postojećim gradskim drvoredima $(3,40-3,58)$. Više od $80 \%$ ispitanika zna da je bagrem vrlo medonosna vrsta i da se koristi u drvnoj industriji.

Ključne riječi: Bagrem, biologija, ekologija, krajobrazna valorizacija, zelene površine Knina. 
B. Dorbić i sur.: Biološke, ekološke i krajobrazne karakteristike bagrema (Robinia pseudoacacia L.) s primjenom na zelenim površinama grada Knina

\begin{abstract}
The black locust (Robinia pseudoacacia L.) is a fast-growing deciduous tree originating from North America that was imported to Europe at the beginning of the 17 th century. It is highly valued in beekeeping, wood industry, forestry and is a highly invasive species. It is most widespread in Northeast Croatia. The species has ornamental features and it is also used in ornamental horticulture. During April and May of 2016 in the territory of the city of Knin a low representation of this species was observed on gardens, yards and green areas. Concerning the maintenance, more care is needed to increase the aesthetic value of this tree species, as it currently ranks as mediocre. The invasiveness of the species also needs to be highlighted and it is reflected in its presence in specific non-landscape areas (freely growing vegetation by the road, forest edges, the railways, etc.). The worst activity of black locust invasiveness is suppression of autochthonous species. Using the survey method the respondents from the territory of the city of Knin and its outskirts evaluated the attractiveness, the agreeableness and the impact of black locust on human mental health with very good grades. They evaluated the use of black locust in economy, landscape picturesqueness and the existing city tree avenues and trees with slightly lower grades (3.40-3.58). Over $80 \%$ of those surveyed are aware that black locust is a highly melliferous species and that it is also used in wood industry.
\end{abstract}

Key words: Black locust, biology, ecology, landscape valorisation, green spaces of Knin

\title{
UVOD
}

Bagrem (Robinia pseudoacacia L.) (slika 1.) je brzorastuće, listopadno drvo porijeklom iz Sjeverne Amerike, a u Europu je uvezen početkom 17. stoljeća. Sa svojim dekorativnim i mirisnim bijelim cvjetovima čest je prizor pejsažnih površina (primorski i kontinentalni dio Hrvatske i susjednih zemalja) tijekom travnja i svibnja (Bojanić Obad Ščitaroci, Obad Ščitaroci, 2004.; Brus, 2004.). Unatoč tomu što je alohtona vrsta u našim submediteranskim područjima „Zrači“ autentičnošću te je prikladna kao parkovna vrsta za pojedinačnu sadnju, sadnju u grupama, drvoredima, za živicu i slično. Dorbić, Temim i Friganović (2015.) slično naglašavaju i za smokvu (Ficus carica L.). Na području Šibensko-kninske županije i grada Knina u hortikulturne namjene koristi se tek sporadično. 


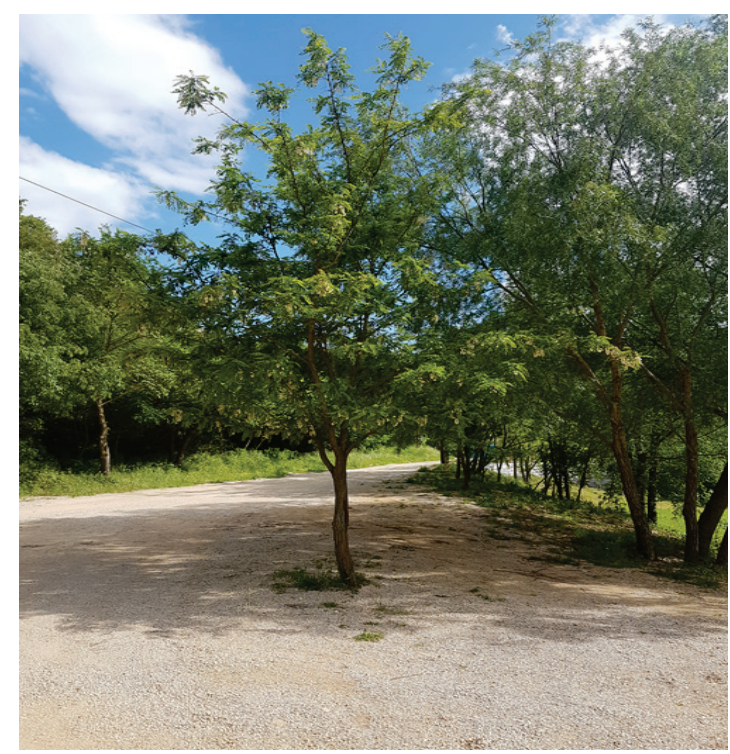

Slika 1. Bagrem (Robinia pseudoacacia L.) (Vučemilović Alegić, 2016.).

Picutre 1 Black locust (Robinia pseudoacacia L.)

Bagrem je i šumska kultura te vrlo invazivna vrsta. Najrasprostranjeniji je u sjeveroistočnom dijelu Hrvatske. Negativnost bagremove invazivnosti ogleda se u potiskivanju autohtonih vrsta.

Ova vrsta se danas širi i uz rubove prometnica i željezničkih pruga, na zapuštenim poljoprivrednim površinama, parkovima, šumskim rubovima, kamenjarama itd. (Nikolić, Mitić i Boršić, 2014.; Grlić, 2005.).

Horvat i Franjić (2016.) navode da najviše problema u šumama Kalnika čini bagrem i to na svim tipovima staništa, kao i u sastojinama svih starosnih skupina. Autori ističu kako su štete posebno značajne u mladim sastojinama, te u sastojinama u fazi obnove, naglašavajući da su u biološkom smislu invazivne vrste trajna opasnost zavičajnoj vegetaciji i bioraznovrsnosti, kao i zdravlju ljudi. Napominju kako je na Kalniku veoma razvijeno pčelarstvo koje upravo opstoji na bagremovoj paši, pa je to još jedan od značajnih razloga njegova uzgoja. Sličnu problematiku invazivnosti vrsta, u konkretnom slučaju za pajasen (Ailanthus alltissima (Mill.) Swingle) iznosi i Kravarščan (2014.).

Maceljski i Mešić (2001.) naglašavaju da je došlo vrijeme da se gradsko zelenilo gdje raste i bagrem mora početi štititi na sličan način kao i voćni 
nasadi sustavom mjera integrirane zaštite, i to uz veće poteškoće zbog specifičnosti urbane sredine. Bagrem među ostalim štetočinama, napada i bijela imela (Viscum album L. ssp. Album) (Idžojtić i sur., 2006.).

\section{MATERIJALI I METODE}

Tijekom izrade ovog rada kao izvor sekundarnih podataka koristile su se različite publikacije te znanstveni i stručni radovi. Kod izvora primarnih podataka obavljena je metoda anketnog ispitivanja na području grada Knina te metoda promatranja prisutnosti i krajobrazne vrijednosti bagrema u vrtovima $i$ zelenim površinama grada tijekom mjeseca travnja i svibnja 2016. godine. Cilj anketnog ispitivanja bio je utvrđivanje korisnosti i krajobrazne vrijednosti bagrema u vrtovima i na zelenim površinama grada Knina. Anketno ispitivanje je provedeno tijekom mjeseca travnja 2016. godine na uzorku od 40 ispitanika $\mathrm{s}$ područja grada Knina i okolice (29 žena i 11 muškarca). Starosna struktura uzorka bila je: do 20 godina 14 , od $20-30$ godina $12,30-40$ godina $6,40-50$ godina 4, 50-65 4 godina ispitanika, a izbor ispitanika je bio slučajan. S obzirom na stupanj obrazovanja struktura uzorka bila je: Srednje obrazovanje $82,5 \%$, visoko stručno obrazovanje $12,5 \%$ te završeni magisterij ili doktorat znanosti 5 \%. U tu svrhu korištena je petostupanjska ljestvica (za mjerenje stavova, percepcija i preferencija o estetskoj, krajobraznoj i uporabnoj vrijednosti bagrema u vrtovima i zelenim površinama grada Knina) s vrijednostima od 1 do 5 te jednostavna „Da/Ne“ pitanja (zatvorenog tipa) za ispitivanje općih saznanja o bagremu. Obrada podataka provedena je mjerilima centralne tendencije, odnosno na osnovi izračuna aritmetičke sredine, standardne devijacije i varijance te u postocima (\%). Statistička obrada podataka izvršena je u programu SPSS 16 za Windows sučelje.

\section{REZULTATI I RASPRAVA}

Biološke i ukrasne karakteristike vrste

Bagrem (Robinia pseudoacacia L.) (=obični bagrem, mirisavi bagrem, prženica, nerodik, bagrema, kapinika itd.) (Horvat i Franjić, 2016.). Pripada porodici Fabaceae lepirnjače, mahunarke i rodu Robinia koji obuhvaća 20 vrsta (Hulina, 2011.). Navedenoj porodici su osim sastavljenih dlanastih i perastih listova, s palistićima, karakteristični i dorziventralni cvjetovi, s dvostrukim ocvijećem. (Bačić i Sabo, 2000.). Bagrem je porijeklom iz Sjeverne Amerike odakle se vrlo brzo proširio po cijelome svijetu. Sjemenke bagrema je 1601. godine u Europu prenio francuski vrtlar Jean Robin, po kojem je bagrem 
dobio ime (Nikolić, Mitić i Boršić, 2014.). U Republici Hrvatskoj je zabilježen početkom 20. stoljeća (iako je najvjerojatnije prisutan od ranije) i rasprostranjen je uglavnom po čitavoj državi, s izuzetkom gorsko-planinskoga područja (Horvat i Franjić, 2016.). Vrsta je širokokultivirana i naturalizirana u SAD-u i Europi, sjevernoj i južnoj Africi, dijelovima Azije, Australiji, na Novom Zelandu, u Kanadi i na jugu južne Amerike (Nikolić, Mitić i Boršić, 2014.). U početku je uzgajan isključivo kao parkovna vrsta, no poslije je postao i vrlo pogodna vrsta za pošumljavanje pustih, opožarenih terena, pijesaka i bujičnih područja (Rauš, Vukelić i Španjol, 1988.). Bagrem je listopadno drvo koje može narasti u visinu do $25 \mathrm{~m}$ (fanerofit), s prozračnom i svijetlom krošnjom, okruglastom ili duguljastom. Promjer stabla je do $50 \mathrm{~cm}$ (Umeljić, 2004.). Njegov korijen u početku razvija žilu srčanicu dugu 1-1,5 m, a bočne površinske žile duge $20 \mathrm{~m}$ i više razvija kasnije. Korijenje mu je plitko, gusto, brzog rasta s mogučnošću fiksacije atmosferskog dušika (Nikolić, Mitić i Boršić, 2014.). Krošnja mu je ukrasna, razgranata, svijetla i rijetka, s glatkim i trnovitim granama (http://www.plantea.com.hr/bagrem/\#Karakteristike). Ulogu vrha ima najviša i najjača grana (Potočić i sur., 1980.). Veće grane su malo vijugave, usmjerene prema nagore, dok su mlade grane viseće ili vodoravne (Godet, 2000.). Kora mladog stabla je glatka siva; starija kora je sivosmeđe boje, zadebljala i uzdužno mrežasto raspucala, sadrži otrovni toksalbumin robin. Stara kora se može ljuštiti (Potočić i sur., 1980.). Listovi su dekorativni, neparno perasto sastavljeni od 9 do 21 liski, koje su duguljasto eliptične, zaobljenog do urezanog vrha ponekad sa šiljkom, zaobljene do široko klinaste osnove, cijelog ruba, s peteljčicom. Raspored listova je naizmjeničan, a liske su nasuprotne. Listovi su dugački $20-30 \mathrm{~cm}$, s peteljkama dugačkim $3-4 \mathrm{~cm}$ (Idžojtić, 2011.). Bagrem lista krajem travnja i počekom svibnja, a list otpada krajem listopada (Potočić i sur., 1980.). Cvjetovi su ukrasni, bijeli, mirisni, medonosni, rastu na jednogodišnjiim izbojcima u pazuhu lišća, njih 15-30 združenih u grozdastim cvatovima, do $20 \mathrm{~cm}$ dugog grozda (Godet, 2000.). Početak cvatnje ovisi o nadmorskoj visini te o stupnju osunčanosti površina pod navedenom vrstom (Umeljić, 2004.). Bagrem cvjeta polovicom mjeseca svibnja, a oprašuje se entomofilno. Fiziološku zrelost dostiže u 3-4 godini, a intenzivno rađa tek u 15 do 20 godini (Potočić i sur., 1980.). Prinos meda s 1 ha može biti $1000 \mathrm{~kg}$ (Umeljić, 2004.). Plod je donekle ukrasan, gola mahuna, do $10 \mathrm{~cm}$ duga i $1-1,8 \mathrm{~cm}$ široka, s vanjske strane smeđa, iznutra srebrno sjajna, sa kratkom peteljkom i sa 6 do 8 sjemenki. Plod puca uzdužno. Plodonosi više ili manje svake godine. Sazrijeva tijekom srpnja i kolovoza. Dio mahuna otpadne odmah nakon dozrijevanja, a dio mahuna ostaje na stablu preko cijele zime (Potočić i sur., 1980.). Sjemenke su bubrežaste, maslinastozelene ili smeđe, 
2 do $3 \mathrm{~mm}$ dugačke. Kilogram sjemena sadržava 50000 sjemenki. Sjeme sazrijeva od 140 do 150 dana, a klijavost zadržava i 3 do 4 godine (Nikolić, Mitić i Boršić, 2014.).

Bagrem je u prošlosti uzgajan isključivo u parkovima kao hortikulturna vrsta, no ni danas nije izgubio to značenje zbog svog ukrasnog izgleda debla, krošnje, cvatnje i dr (Rauš, Vukelić i Španjol, 1988.). Osim što je medonosna i ljekovita vrsta bagrem je i izrazito invazivna vrsta. Invazivne vrste često uspješno stvaraju veliki broj reproduktivno sposobnih potomaka te na značajnoj udaljenosti od roditelja biljaka imaju izrazito veliki potencijal širenja na velika područja (Nikolić, Mitić i Boršić, 2014.). Bagrem čini guste populacije, zasjenom istiskuje heliofitne biljke te smanjuje biološku raznolikost. Zbog izrazite prilagođenosti raznim tipovima staništa, bagrem je teško kontrolirati. Mehaničko uklanjanje i paljenje uglavnom ne daju dobre rezultate, zbog dobrog obnavljanja korijenskim izdancima. Dobri se rezultati postižu različitim herbicidima. Premda u SAD-u bagrem ima svoje prirodne patogene, u Europi se pokazao kao visokootporan na gljive i druge patogene (Horvat i Franjić, 2016.). Od herbicida koriste se aminofosfati, s djelatnom tvari glifosat 4\%, a LD50 4320 (Cidokor, Hercules 480 SL, Mentor, Herbocor, Roundap itd) (Glavaš i sur., 2009.).

\section{ŠTETNI ORGANIZMI NA BAGREMU SU:}

\section{VIRUS}

Virus mozaika bagrema (Robinia mosaic viruses)

GLJIVE I PSEUDOGLJIVE

Erysiphe trifolii Grev.

Laetiporus sulphureus (Bull.) Murrill

Nectriacinna barina (Tode) Fr

Perenniporia fraxinea (Bull.) Ryvarden

Peronospora cytisi Rostr.

Phloeospora robiniae (Lib.) Höhn.

Phyllosticta advena Pass.

Verticilliumalbo-atrum Reinke \& Berthold

POLUPARAZITSKA BILJKA

Viscum album $\mathrm{L}$.

\section{ŠTETNICI}

Euproctis chrysorrboea L.

Leperesin usvarius F.

Lymantria dispar $\mathrm{L}$.

Nematustibialis Newman 
Orgya antiqua $\mathrm{L}$

Parectopa robiniella Clemens

Phyllonorycter robiniella Clememens

Vasates robiniae Nalepa (Cvjetković, 2016.).

Tako su u novije vrijeme u Hrvatskoj otkriveni bagremova lisna uš (Appendiseta robiniae) (Gotlin i sur.) i bagremov moljac miner (Parectopa robiniella Clem.), štetnici koji su u Hrvatskoj otkriveni 1984. odnosno 1983. g. Tijekom 2001. godine u Hrvatskoj je otkriven i treći štetnik bagrema američkog podrijetla, koji je u Europi otkriven 1983. moljac vrećastih mina bagrema (Phyllonorycter robiniella Clem.) (Maceljski i Mešić, 2001.).

Ekološke osobine vrste

Bagrem je na području Hrvatske široko rasprostranjen. Staništa su mu nizinska i brežuljkasta, ponekad brdska područja, u svijetlim šumama i nasipima (Godet, 2000.). U šumama na području kontinentalne Hrvatske jedna je od zastupljenijih vrsta drveća koja preferira suha i pjeskovita tla bogata hranivima, premda raste i na najoskudnijim tlima. Najveće površine se pod bagremom u Hrvatskoj nalaze u Moslavini, Podravini, Hrvatskom zagorju te u istočnoj Slavoniji (Ilok i Vukovar). Ukupne površine pod bagremom u Hrvatskoj iznose oko 20.000 ha (Vukelić i Rauš, 1988.).

Najrasprostranjeniji je u sjeveroistočnom dijelu, gdje raste na raznim tipovima tala od smeđih, vlažnih crnica do različitih tipova pseudogleja. Klimu na području sjeveroistočne Hrvatske karakterizira srednja temperatura od 10,1 do $10,8{ }^{\circ} \mathrm{C}$. Srednja godišnja količina oborina iznosi 622 do $733 \mathrm{~mm}$ (Rauš, Vukelić i Španjol, 1988.).

Vrsta nabolje raste na rastresitom, rahlom, dubokom i plodnom tlu gdje može maksimalno razviti korijenov sustav. Slabo raste na kamenitim tlima, na tlima gdje voda stagnira ili gdje je visoka razina podzemne vode. Bagrem je izrazito heliofitna vrsta, za rast i razvoj mu je potrebno mnogo svjetla. Slabo je otporan na vjetar i snijeg dok je na ekstremno niske temperature zraka neotporan (Potočić i sur., 1980. ).

Valorizacija bagrema na zelenim površinama grada Knina

Tijekom terenskog istraživanja u travnju i svibnju 2016. godine na području grada Knina utvrđeno je da je bagrem vrsta koja se malo koristi na zelenim površinama, vrtovima, okućnicama i dvorištima (Tablica 1). Vrsta se u krajobraznom oblikovanju najviše koristi kao pojedinačno stablo ili kao dendroelement u manjim grupama. U pogledu održavanja i njege nužno je posvetiti 
B. Dorbić i sur.: Biološke, ekološke i krajobrazne karakteristike bagrema (Robinia pseudoacacia L.) s primjenom na zelenim površinama grada Knina

više pažnje boljem formiranju krošnje te fitosanitetskim mjerama kako bi stabla dobila na većoj estetskoj vrijednosti, koja je sada na razini prosječnosti, ocjene dobar (3). Uviđa se i invazivno ponašanje vrste, što se ogleda u zastupljenosti na određenim površinama poput slobodnorastuća vegetacija uz cestu, rubove šume, željezničku prugu itd., te daje određenu krajobraznu vrijednost području posebice u periodu njegove cvatnje. Potrebno je kroz edukaciju građana iskazati na važnosti uporabe naših autentičnih dendroloških vrsta.

\section{Tablica 1. Lokacije s bagremom na području grada Knina}

Table 1 Locations with black locust in the city of Knin

\begin{tabular}{|c|c|c|c|}
\hline $\begin{array}{l}\text { R. br. } \\
\text { (Oznaka } \\
\text { na karti) }\end{array}$ & $\begin{array}{l}\text { Lokacija s bagremom kao } \\
\text { dendro-elementom }\end{array}$ & $\begin{array}{l}\text { Broj } \\
\text { stabala }\end{array}$ & $\begin{array}{l}\text { Ocjena estetskih i } \\
\text { funkcionalnih } \\
\text { vrijednosti }\end{array}$ \\
\hline 1. & Ulica Drniška cesta br. 14 i 46 & 5 & 3 \\
\hline 2. & Rekreacijski teren „Marunuša“ & 5 & 4 \\
\hline 3. & Na trgu Matije Gupca (stara tržnica) & 4 & 3 \\
\hline 4. & Krešimirova ulica br. 28 & 1 & 3 \\
\hline 5. & Vrt Veleučilišta „Marko Marulić“ & 1 & 3 \\
\hline 6. & Autobusni kolodvor Knin & 3 & 2 \\
\hline 7. & Uz željezničku prugu & 109 & 4 \\
\hline 8. & $\begin{array}{l}\text { Zelena površina nasuprot zgrade gradske } \\
\text { uprave }\end{array}$ & 2 & 3 \\
\hline 9. & $\begin{array}{l}\text { Ulica dr. F. Tuđmana br. } 8,10 \text { i } 12 \text { (preko } \\
\text { puta Doma zdravlja u Kninu) }\end{array}$ & 13 & 2 \\
\hline 10. & Ulica dr. Franje Tuđmana br. 7 & 1 & 3 \\
\hline 11. & $\begin{array}{l}\text { Ulici Gojka Šuška br. } 9 \text { (kao pojedinačna } \\
\text { stabla u dvorištu ispred zgrade) }\end{array}$ & 2 & 3 \\
\hline 12. & Ulica Gojka Šuška br. 33 & 1 & 4 \\
\hline 13. & $\begin{array}{l}\text { Ulica braće Radić (s desne strane preko } \\
\text { puta stambenih zgrada) }\end{array}$ & 3 & 3 \\
\hline 14. & Dvorište dječjeg vrtića „Cvrčak“ & 3 & 4 \\
\hline 15. & Ulica 7. Gardijske brigade br. 34 & 1 & 3 \\
\hline 16. & Getaldićeva ulica br. 4 (u dvorištu zgrade) & 1 & 3 \\
\hline \multirow[t]{2}{*}{17.} & Ulica 4. gardijske brigade & 3 & 2 \\
\hline & & $\begin{array}{c}\text { Ukupno } \\
(157) \\
\text { stabala }\end{array}$ & $\begin{array}{c}\text { Prosječna ocjena } \\
\text { (3) }\end{array}$ \\
\hline
\end{tabular}


B. Dorbić i sur.: Biološke, ekološke i krajobrazne karakteristike bagrema (Robinia pseudoacacia L.) s primjenom na zelenim površinama grada Knina

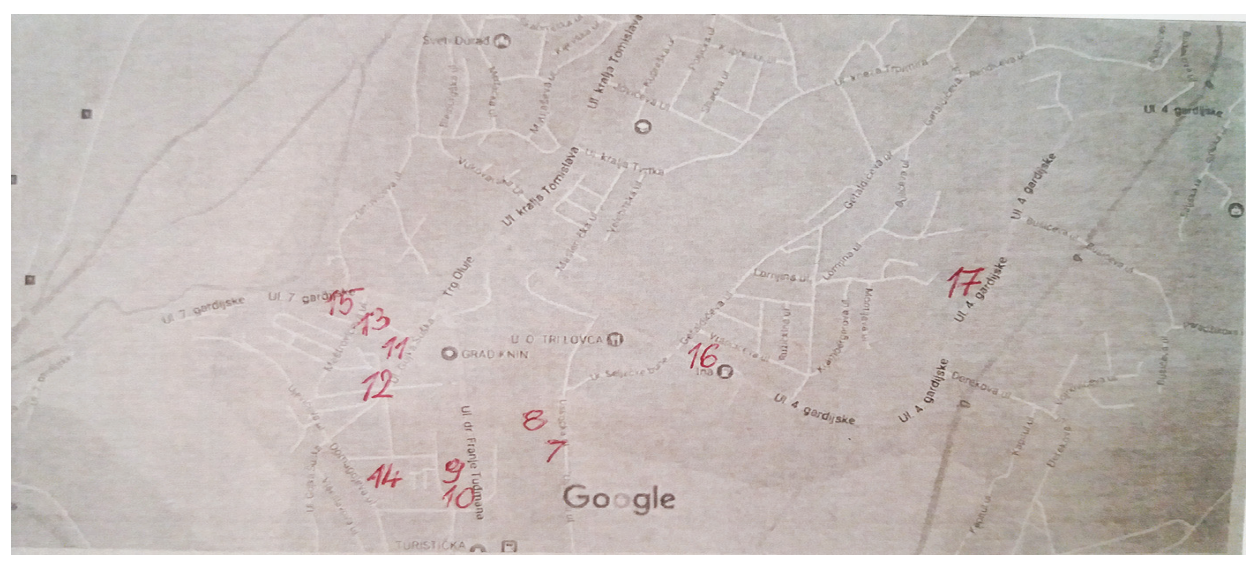

Slika 2. Lokacije s bagremom na području grada Knina-Pogled-1 (Google maps)

Picutre 2 Locations with black locust in the area of Knin-View-1

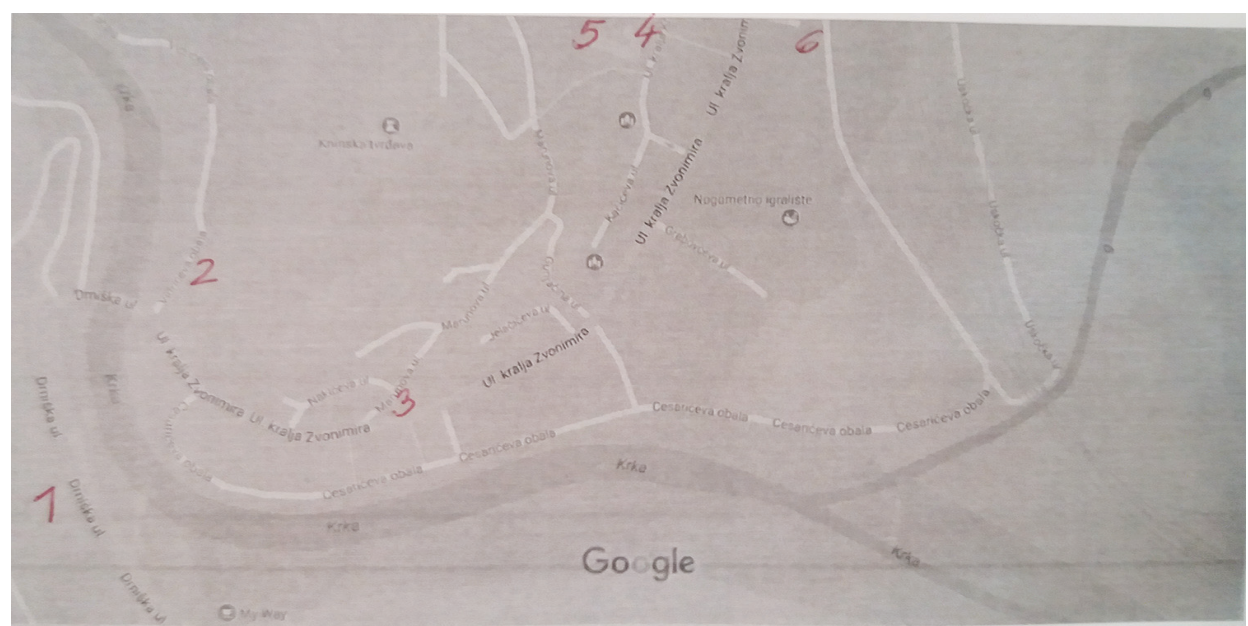

Slika 3. Lokacije s bagremom na području grada Knina-Pogled-2 (Google maps)

Picutre 3 Locations with black locust in the area of Knin-View-2 
B. Dorbić i sur.: Biološke, ekološke i krajobrazne karakteristike bagrema (Robinia pseudoacacia L.) s primjenom na zelenim površinama grada Knina

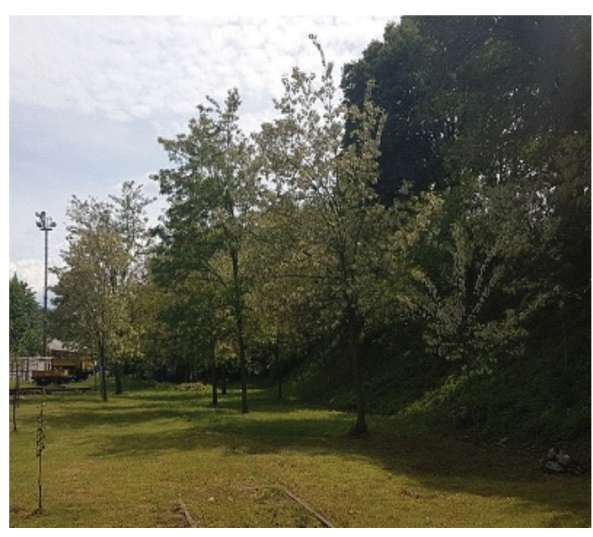

Slika 4. Bagrem uz željezničku prugu

Picutre 4 Black locust along the railway line

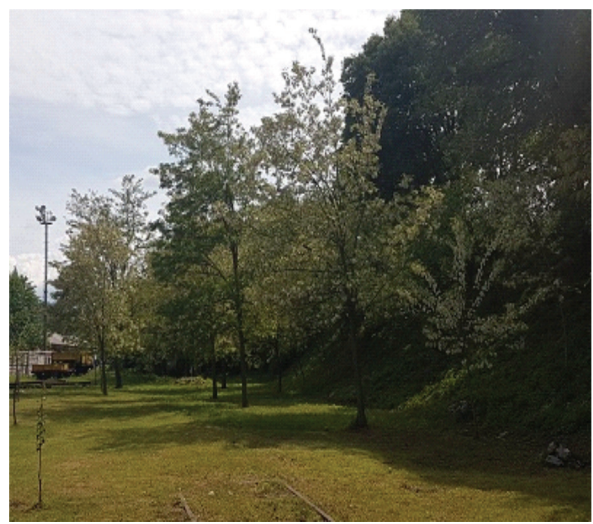

Slika 6. Bagrem u ulici 7. Gardijske brigade br.34

Picutre 6 Black locust in the street 7. Gardijske brigade no.34

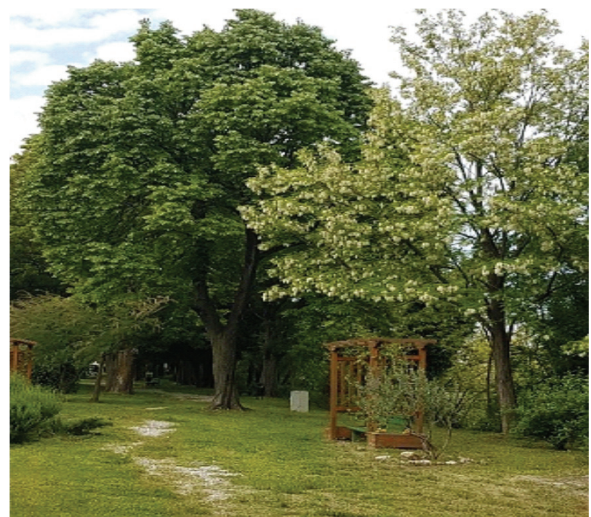

Slika 5. Bagrem na zelenoj površini nasuprot zgrade gradske uprave

Picutre 5 Black locust in the green area opposite the building of the city administration

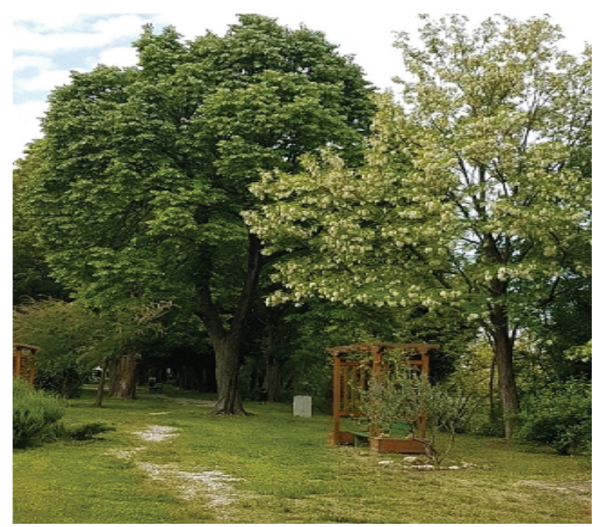

Slika 7. Bagrem u ulici dr. Franje Tuđmana br. 7

Picutre 7 Black locust in the street dr. Franje Tuđmana no.7

Slika 4 - 7 / Picutre 4 - 7: Vučemilović Alegić, 2016. 
B. Dorbić i sur.: Biološke, ekološke i krajobrazne karakteristike bagrema (Robinia pseudoacacia L.) s primjenom na zelenim površinama grada Knina

Rezultati anketnog istraživanja

$\mathrm{U}$ istraživačkom dijelu rada provedeno je anketno ispitivanje s ciljem utvrđivanja važnosti primjene, dekorativnosti i uporabe bagrema u vrtovima $\mathrm{i}$ zelenim površinama Knina.

Tablica 2. Stavovi, percepcije i preferencije stanovnika Knina i okolice o primjeni bagrema u vrtovima i zelenim površinama

Table 2 Attitudes, perceptions and preferences of citizens in Knin and its surroundings on the black locust in gardens and green areas

\begin{tabular}{|c|l|c|c|c|}
\hline $\begin{array}{c}\text { Redni } \\
\text { broj }\end{array}$ & \multicolumn{1}{|c|}{ Pitanje } & $\begin{array}{c}\text { Aritmetička } \\
\text { sredina }\end{array}$ & $\begin{array}{c}\text { Standardna } \\
\text { devijacija }\end{array}$ & Varianca \\
\hline 1. & $\begin{array}{l}\text { 1. Doživljaj ugodnosti prisutnosti bagrema } \\
\text { na zelenim površinama Knina }\end{array}$ & 3,83 &, 813 &, 661 \\
\hline 2. & $\begin{array}{l}\text { Ocjena atraktivnosti prisutnosti bagrema } \\
\text { na zelenim površinama Knina }\end{array}$ & 3,85 &, 834 &, 695 \\
\hline 3. & $\begin{array}{l}\text { Ocjena prihvatljivosti bagrema za vlastiti } \\
\text { vrt, okućnicu ili dvorište. }\end{array}$ & 3,60 &, 928 &, 862 \\
\hline 4. & $\begin{array}{l}\text { Ocjena bagrema u krajobrazu na duševno } \\
\text { zdravlje čovjeka }\end{array}$ & 4,15 &, 770 &, 592 \\
\hline
\end{tabular}

Tablica 3. Stavovi, percepcije i preferencije o korisnosti i krajobraznoj vrijednosti bagrema

Table 3 Attitudes, perceptions and preferences on the usefulness and landscape value of black locust

\begin{tabular}{|c|l|c|c|c|}
\hline $\begin{array}{c}\text { Redni } \\
\text { broj }\end{array}$ & \multicolumn{1}{|c|}{ Pitanje } & $\begin{array}{c}\text { Aritmetička } \\
\text { sredina }\end{array}$ & $\begin{array}{c}\text { Std. } \\
\text { Devijacija }\end{array}$ & Varianca \\
\hline 1. & $\begin{array}{l}\text { Uloga bagrema u gospodarskoj prošlosti } \\
\text { Knina za pošumljavanje područja u } \\
\text { pčelarstvu i šumarstvu }\end{array}$ & 3,08 & 1,141 & 1,302 \\
\hline 2. & $\begin{array}{l}\text { Uloga bagrema za buduća } \\
\text { pošumljavanja, šumarstvu i pčelarstvu } \\
\text { Knina i okolice }\end{array}$ & 3,58 & 1,152 & 1,328 \\
\hline 3. & $\begin{array}{l}\text { Ocjena postojećih pojedinačnih } \\
\text { drvoreda i pojedinačnih stabala bagrema } \\
\text { u zelenim površinama Knina }\end{array}$ & 3,40 &, 810 &, 656 \\
\hline 4. & $\begin{array}{l}\text { Ocjena mjesta bagrema u krajobraznoj } \\
\text { slikovitosti Knina i okolice }\end{array}$ & 3,53 &, 716 &, 512 \\
\hline
\end{tabular}


B. Dorbić i sur.: Biološke, ekološke i krajobrazne karakteristike bagrema (Robinia pseudoacacia L.) s primjenom na zelenim površinama grada Knina

Iz tablice 2. se uočava da stanovnici Knina i okolice s ocjenom vrlo dobar 4,15 vrednuju utjecaj bagrema u krajobrazu na duševno zdravlje čovjeka te atraktivnost i ugodnost vrste na zelenim površinama s ocjenama 3,85 i 3,83. Nešto niže vrijednosti su dodijeljene prihvatljivosti bagrema za vlastiti vrt, okućnicu ili dvorište 3,60 .

Iz tablice 3. se uočava da stanovnici Knina i okolice s ocjenom vrlo dobar vrednuju primjenu bagrema za buduća pošumljavanja, u šumarstvu i pčelarstvu $(3,58)$, kao i za mjesto bagrema u krajobraznoj slikovitosti Knina $(3,53)$. Nešto manje ocjene ispitanici su dodijelili postojećim pojedinačnim drvoredima i pojedinačnim stablima bagrema na zelenim površinama grada Knina $(3,40)$. Najniža ocjena dodijeljena je upotrebi bagrema u gospodarskoj prošlosti Knina za pošumljavanje područja u šumarstvu i pčelarstvu $(3,08)$.

\section{Tablica 4. Poznavanje općih saznanja o bagremu}

\section{Table 4 General knowledge of black locust}

\begin{tabular}{|c|l|c|c|}
\hline $\begin{array}{c}\text { Redni } \\
\text { broj }\end{array}$ & \multicolumn{1}{|c|}{ Pitanje } & $\begin{array}{c}\text { DA } \\
\text { Postoci (\%) }\end{array}$ & $\begin{array}{c}\text { NE } \\
\text { Postoci (\%) }\end{array}$ \\
\hline 1. & $\begin{array}{l}\text { Da li ste znali da je bagrem medonosna } \\
\text { vrsta } ?\end{array}$ & 87,5 & 12,5 \\
\hline 2. & $\begin{array}{l}\text { Da li ste znali da je bagrem vrlo invazivna } \\
\text { vrsta }\end{array}$ & 30 & 70 \\
\hline 3. & $\begin{array}{l}\text { Da li ste znali da je bagrem alohtona } \\
\text { (nezavičajna) vrsta ? }\end{array}$ & 22,5 & 77,5 \\
\hline 4. & $\begin{array}{l}\text { Da li ste znali da se bagrem koristi u drvnoj } \\
\text { industriji } ?\end{array}$ & 80,0 & 20,0 \\
\hline 5. & $\begin{array}{l}\text { Da li ste znali da bagrem ima vjetrozaštitnu } \\
\text { ulogu u prostoru ? }\end{array}$ & 47,5 & 52,5 \\
\hline
\end{tabular}

Iz tablice 4. je razvidno da $87,5 \%$ ispitanika zna da je bagrem vrlo medonosna vrsta. Tek $30 \%$ ispitanika je potvrdilo da je bagrem izrazito invazivna vrsta, a $22,5 \%$ ispitanika je potvrdilo da je bagrem alohtona (nezavičajna vrsta). $80 \%$ ispitanika zna da se bagrem koristi u drvnoj industriji, dok 47,5 \% ispitanika ima saznanja da bagrem ima vjetro-zaštitnu ulogu u prostoru. 


\section{ZAKLJUČAK}

Metodom promatranja na istraživanom području utvrđeno je da je bagrem zastupljen na zelenim površinama Knina kao soliter ili u skupinama. U vrtovima, okućnicama i dvorištima grada Knina bagrem nije često korišten kao ukrasna vrsta. U pogledu održavanja i njege nužno je posvetiti više pažnje boljem formiranju krošnje te fitosanitetskim mjerama kako bi stabla dobila na većoj estetskoj vrijednosti, koja je sada na razini prosječnosti. Uviđa se i invazivno ponašanje vrste što se ogleda $u$ zastupljenosti na određenim površinama slobodno rastuće vegetacije uz cestu, rubove šume, željezničku prugu, što daje određenu krajobraznu vrijednost području posebice u periodu njegove cvatnje. Negativnost bagremove invazivnosti je potiskivanje autohtonih vrsta. Od herbicida za suzbijanje bagrema na neželjenim mjestima koriste se aminofosfati, s djelatnom tvari glifo sat 4\%, a LD50 4320. Bagrem ima vrlo važnu ulogu u obnavljanju i sadnji novih šuma. Veoma se često koristi u drvoredima za zaštitu od bočnih vjetrova. Drvo bagrema ima odlične tehničke osobine, te je vrlo cijenjena medonosna vrsta.

Temeljem anketnog ispitivanja percepcije stanovnika Knina i okolice o primjeni bagrema na području grada Knina došlo se do sljedećih spoznaja:

Stanovnici Knina i okolice s ocjenom vrlo dobar vrednuju sljedeće: utjecaj bagrema u krajobrazu na duševno zdravlje čovjeka, atraktivnost te ugodnost bagrema na zelenim površinama, prihvatljivost bagrema za vlastiti vrt, okućnicu ili dvorište.

Također s ocjenom vrlo dobar vrednuju primjenu bagrema za buduća pošumljavanja, u šumarstvu i pčelarstvu kao i za mjesto bagrema u krajobraznoj slikovitosti Knina.Najviše ispitanika zna da je bagrem vrlo medonosna vrsta te da se bagrem koristiti u drvnoj industriji.

Rad je izvod iz Završnog rada diplomantice Božane Vučemilović Alegić pod naslovom:

„Biološke, ekološke i krajobrazne osobine bagrema (Robinia pseudoacacia L.) s primjenom na zelenim površinama grada Knina“. 


\section{LITERATURA}

ANONYMOUS. (1999.): Med pčelarenje i običaji. Pučko otvoreno učilište Zagreb.

BAČIĆ, T., SABO, M. (2006.): Filogenetska sistematika stablašicaembriophyta-cormophyta. Sveučilište J. Jurja Strossmayera. Osijek.

BRUS, R. (2004.): Drevesne vrste na Slovenskem. Mladinska knjiga.

BUČAR, M. (2008.): Medonosne biljke kontinentalne Hrvatske. Učiteljski fakultet Zagreb-podružnica Petrinja.

BUTIN, H., NIENHAUS, F., BOHMER, B. (2003.): Atlas bolesti i štetnika na drveću i grmlju. ITD Gaudeamus d.o.o. Požega.

CALL, L. J., NILSEN, E. T. (2005.): Analysis of interactions between the invasive tree-of-heaven (Ailanthus altissima) and the native black locust (Robinia pseudoacacia). Plant Ecology 176(2): 275-285.

DOMAC, R. (1994.): Flora Hrvatske. Priručnik za određivanje bilja. Zagreb.

DORBIĆ, B., TEMIM, E., FRIGANOVIĆ, E. (2015.): Dendrological landscape valorisation of the common fig (Ficus carica L.) in the gardens of Šbenik. Works of the Faculty of Forestry University of Sarajevo. No. 2: 25-36.

FRANJIĆ, J., ŠKVORC, Ž. (2010.): Šumsko drveće i grmlje Hrvatske. Sveučilište u Zagrebu - Šumarski fakultet, Zagreb.

GLAVAŠ, M., GLAVAŠ, S., BUDINŠČAK, M., VUKADIN, A. (2009.): Štetočinje i zaštita biljaka u rasadniku „Podbadanj“ od 1993. do 2007. godine. Šumarski list br. 11-12, CXXXIII: 623-627.

GODET, J. D. (2000.): Godetov vodić-Drveće i grmlje. Naklada C d.o.o. Zagreb.

GOTLIN-ČULJAK, T., IGRC-BARČIĆ, J., BAŽOK, R., GRUBIŠIĆ, D. (2005.): Aphid fauna (Hemiptera: Aphidoidea) in Croatia, Entomol. Croat: 57-69.

GRLIĆ, LJ. (2005.): Enciklopedija samoniklog jestivog bilja. Ex. Libris. Rijeka. HORVAT, G., FRANJIĆ, J. (2016.): Invazivne biljke kalničkih šuma. Šumarski list 1-2: 53-64. 
HULINA, N. (2011.): Više biljke stablašice. Golden marketing-Tehnička knjiga. Zagreb.

IDŽOJTIĆ, M., GLAVAŠ, M., ZEBEC, M., PERNAR, R., BEUK, P., PRGIĆ, I. (2006.): Intenzitet zaraze žutom i bijelom imelom na području uprava šuma podružnica Vinkovci i Nova Gradiška. Šumarski list br. 9-10, CXXX: 399-409.

IDŽOJTIĆ, M. (2011.): Dendrologija-List. Šumarski fakultet Sveučilišta u Zagrebu.

KRAVARŠČAN, M. (2014.): Jasen (Ailanthus altissima (Mill.) Swingle)Strana invazivna biljna vrsta u Hrvatskoj. Glasilo biljne zaštite Vol 14, br. 3: 254-261.

MACELJSKI, M., MEŠIĆ, A. (2001.): Phyllonorycter robiniella Clemens (Lep. Gracillariidae) - novi štetnik bagrema u Hrvatskoj. Agriculturae conspectus scientificus, Vol. 66 No. 4: 225-230.

NIKOLIĆ, T., MITIĆ, B., BORŠIĆ, I. (2014.): Flora Hrvatske-Invazivne biljke. Alfa d.d. Zagreb.

POTOČIĆ, Z., I SUR. (1980.): Šumarska enciklopedija. Jugoslavenski leksikografski zavod. Zagreb.

RAUŠ, Đ., VUKELIĆ, J., ŠPANJOL, Ž. (1988.): Bagremova šuma kao ispaša za pčele. Šumarski list CXII, 351: 351-360.

UMELJIĆ, V. (2004.): U svijetu cvijeća i pčela-Atlas medonosnog bilja I. dio. Izdavač: Ilija Borković-Sinj., Split.

VUČEMILOVIĆ ALEGIĆ, B. (2016.). Biološke, ekološke i krajobrazne osobine bagrema (Robinia pseudoacacia L.) s primjenom na zelenim površinama grada Knina. Završni rad. Veleučilište „Marko Marulić“ u Kninu.

VUKELIĆ, J., RAUŠ, Đ. (1988.): Šumarska fitocenologija i šumske zajednice u hrvatskoj. Šumarski fakultet Sveučilišta u Zagrebu.

http://www.plantea.com.hr/bagrem/\#Karakteristike (preuzeto: 08.05.2017.). 
B. Dorbić i sur.: Biološke, ekološke i krajobrazne karakteristike bagrema (Robinia pseudoacacia L.) s primjenom na zelenim površinama grada Knina

\section{Adresa autora - Author's address:}

dr. sc. Boris Dorbić, pred.

Emilija Friganović, v. pred.

Anita Pamuković, pred.

Božana Vučemilović Alegić, Studentica (diplomantica);

Veleučilište „Marko Marulić“ u Kninu, odjel poljoprivrede krša, Krešimirova 30, 22300 Knin

Prof. dr. sc. Elma Temim

mr. sc. Alisa Hadžiabulić

Univerzitet "Džemal Bijedić" Mostar, Agromediteranski fakultet, Univerzitetski kampus bb, Mostar, Bosna i Hercegovina. 